\title{
MY INSPIRATIONS FROM TRADITIONAL SYRIAN ARCHITECTURE
}

I visited Syria in 1982 in order to help local architects in the design of Sport City in Aleppo. I was already slightly acquainted with Arab architecture due to my earlier short visit to the Emirates. But this time it was different, I had big projects to discuss and to put forward my architectural propositions, and it was in the urban context of this magnificent town with a rich cultural history. So I began to take afternoon walks in the town with my sketchbook. I stopped before every building that, according to my knowledge and my feeling, could help me better understand the local traditions and I made some quick black-and-white sketches. I was fascinated by some characteristic delicate stone details, by the meandering, narrow streets and by the slender minarets. The powerful citadel of Aleppo impressed me with its ramparts and towers.

The Sport City Project included two stadiums, a sports hall and a swimming pool. The sports hall was planned for twelve thousand spectators and was multifunctional; the swimming pool had an Olympic programme with eight thousand spectator seats. First, I tried to make use of dome-shaped forms, as there were plenty of domes in Aleppo and every Arab town. But then I decided not to repeat this common shape, but rather to rely upon the convex lines present in Bedouin tents, that gave my architecture a modern look and was structurally more interesting.

The projects in Aleppo were my first step in the field of my Syrian architectural activity. The Syrian sports authorities wanted to host the 17th Mediterranean Games and launched an international architectural competition for 'Sport City' in Latakia on the Syrian coast, where the Games were planned. I was awarded first prize and was consequently nominated as chief architect of the project. The design was to be executed in the local office in Latakia, 
with the help of some Polish architects and engineers, working together with a young Syrian team.

Waiting for the results of the competition, I spent some time in the office in Damascus, where I studied the possibility of building a modern hotel in one of the most beautiful khans in Syria, Khan Asad Basha. In the meantime, I had the opportunity to admire the magnificent mosques and palaces of the old town and to make my paintings and drawings. The architecture of Damascus is different from that of Latakia; we can see greater influence of the Turkish style there.

As soon as all formalities, connected with my winning project for the Mediterranean Games, were settled, I went to the Latakia office and we started our work. It was a really hectic time, but even so, I still did not neglect my artistic hobby. The town of Latakia could not offer us as many picturesque, old monuments as we could see in Aleppo or Damascus. I used to organize excursions to the countryside almost every Friday. We visited Ugarit, Ebla, Crusader's castles, Bedouin tents in Palmyra and Apamea and many other interesting places. We made a three-hour-stop in every place in order to have enough time for painting and drawing.

I soon realized that the simple transfer of traditional Syrian architecture to modern, up-to-date sports buildings could have woeful results, and Arabic decoration would only trivialize the effect. Instead, I decided to make use of organic design, better suited for sports architecture in such a beautiful place. I also decided to continue my predilection towards the architectural exposition of modern structure.

The urban solution of Sport City was based upon organically shaped, meandering pathways. The main walkway of the complex was shaped like an arc and connected the road from the city with the sea. The main sports buildings were located around this axis: main stadium, sports halls and a swimming pool. In order to reduce the usually very large shape of the main stadium, I decided to make it partly from excavated soil, like a kind of a mound (tall). Only the main stand facing the sea was designed as a solid building and covered with concave waves, reminiscent of the undulating shapes of desert tents. The complex of sports halls was divided into five convex-concave forms for the same reason. The open swimming pool was separated like a shell into two parts: for competition and for recreation. There were also other smaller buildings, all clad with beautiful yellowish local stone on inclined walls. The yacht club near the seashore was shaped like a boat, and the workshop - like a caravanserai. 
As chief architect, I had to supervise the technical projects of every building and, afterwards, their execution. Even so, after my everyday duties, I still had enough time to continue studying and drawing the Syrian architecture and landscape. When the rumours of my hobby reached the art-friendly authorities, I received an invitation to make an exhibition of my drawings and watercolours in the National Museum in Aleppo. After that, I was invited to exhibit my works in Latakia and Damascus.

As well as the major project of Sport City in Aleppo and Latakia, I was entrusted with the project of a suburban villa in Damascus for the ruling family. This was something quite different from my usual architectural subject matter of large-scale sports facilities. But my studies and drawings of traditional Syrian architecture proved very useful for undertaking that task. After some alternative designs, an interesting solution was proposed and accepted. This time, I made a more sculptural project than usual, playing with protruding windows and ogival arcs. The living rooms were located around an inner-patio with a fountain in the middle and a traditional $\bar{\imath} w \bar{a} n$. The result was very satisfactory, both for the client and the author: the villa was modern, but at the same time in harmony with Arab tradition.

After the 17th Mediterranean Games had finished in Latakia in 1987, I returned home. Once in Warsaw, I received an unexpected commission from Syria: the project of a holiday villa on the seaside near Latakia. The place was very beautiful, on a steep rock with a magnificent view towards a holy Phoenician mountain near the Turkish border. After my visit there, I designed a one-level villa hidden between rocks and covered by a garden on the roof. The walls were made of local rock, imitating a natural shape. The main entrance was shaped like the Ugarit gate and real stalactites from a neighbouring cave were placed in the living room. There were Roman style mosaics on the floor and sky domes, typical for a hammām.

When my Syrian peregrinations had finished, I set to my architectural work in Poland. My first projects were made with some Oriental influence; but I had to return to my previous style, only enriched by my Syrian adventures. I also continued my paintings in Poland; after five years in Syria I had become accustomed to it. This was undoubtedly the legacy of my artistic work in Aleppo, Damascus and Latakia.

Already in Poland, I had had the unique chance to design a project for a mosque and Islamic Cultural Centre in Warsaw, that was planned in the Saska Kępa district, near the Vistula river and close to a wide East-West thoroughfare, in quiet Bajońska Street. The architecture of the religious 
complex, designed in the year 1990, evidently carried associations with traditional Islamic art, both in its general shape as well as in its details. The main entrance to the prayer hall led through a gate and a courtyard with a fountain. An oval dome covered the men's prayer hall and, under it, inside the hall, there was another wooden, octagonal, smaller dome, for thermal protection. The women's prayer space was situated in the gallery. There was a free-standing fifty-five metre high minaret. The cultural centre, closely connected with the mosque, contained a conference hall, exhibition room, club, library, classrooms and guest rooms.

Because of difficulties with the ownership of the plot, as well as some other ones, the project was not completed at that time and finally abandoned. Now the plot hosts an apartment building. Of the mosque, only historical drawings and memories remain...

The Syrian drawings and paintings, illustrating the article, were made from nature by the author between 1982 and 1984 . 


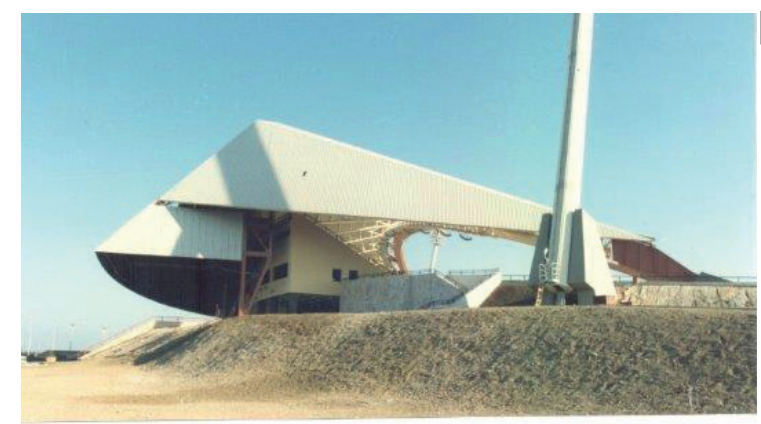

Fig. 1. The Sport City in Latakia. Down left - the Olympic Swimming Pool, right up - the Sport Hall. Main construction was designed as circular arches, and between them the ondulating hanged roofs - an inspiration taken from Bedouin tents

MAIN OLYMPIC STADIUM IN LATAKIA
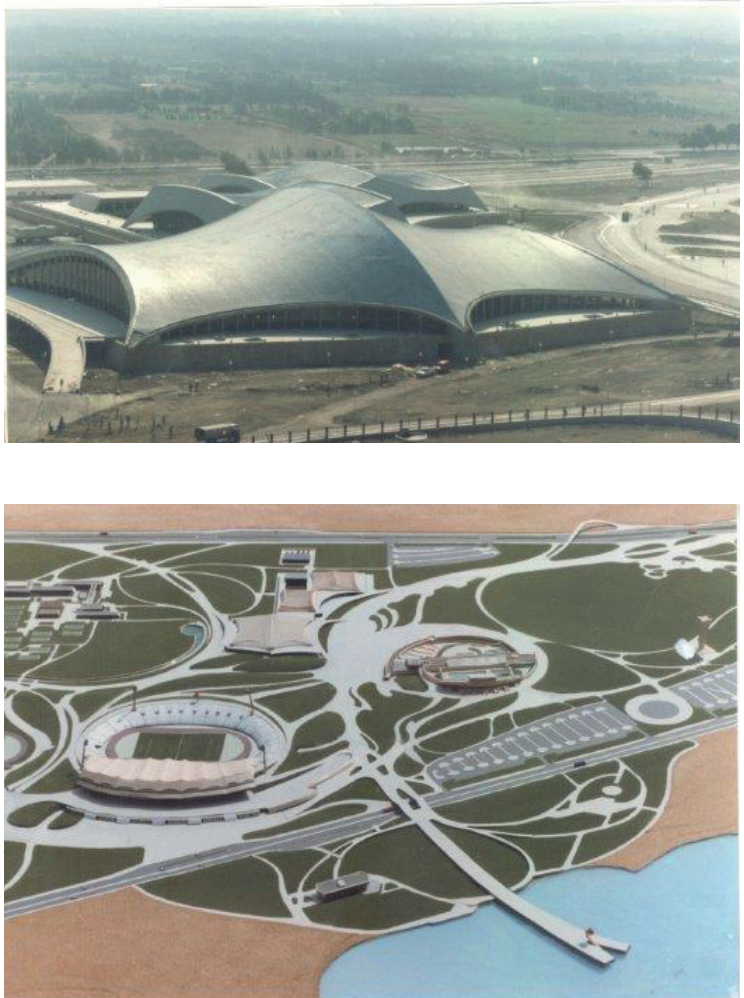

OLYMPIC CENTRE IN LATAKIA, SYRIA

Fig. 2. In the upper photo: the

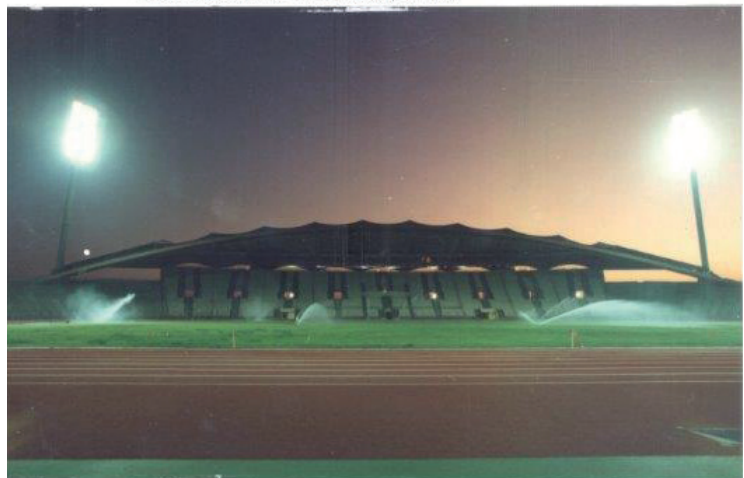
organic master plan of the Latakia Sport City. Down: ondulating roofs of the stadium main tribune 


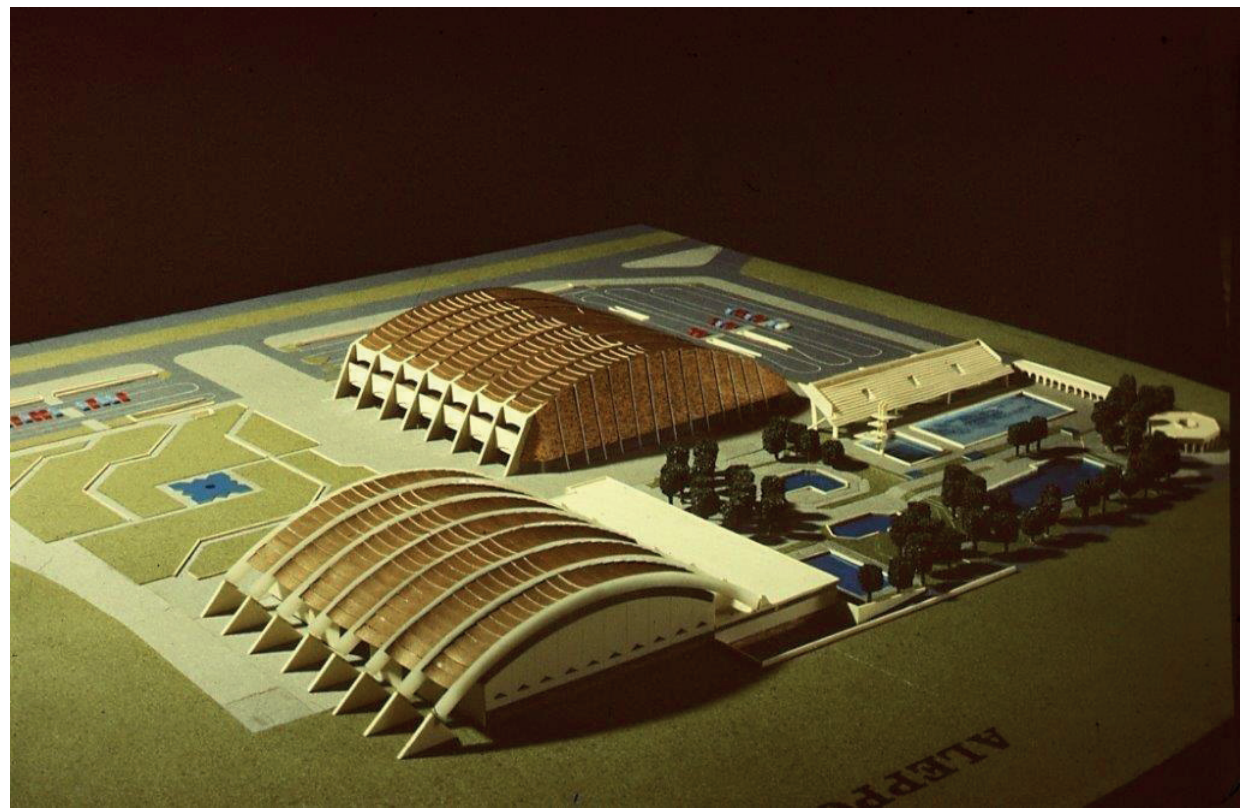

Fig. 3. In the upper photo: cantilevered roof of the main stadium in Latakia, down: the Sport Hall complex with hanging roofs

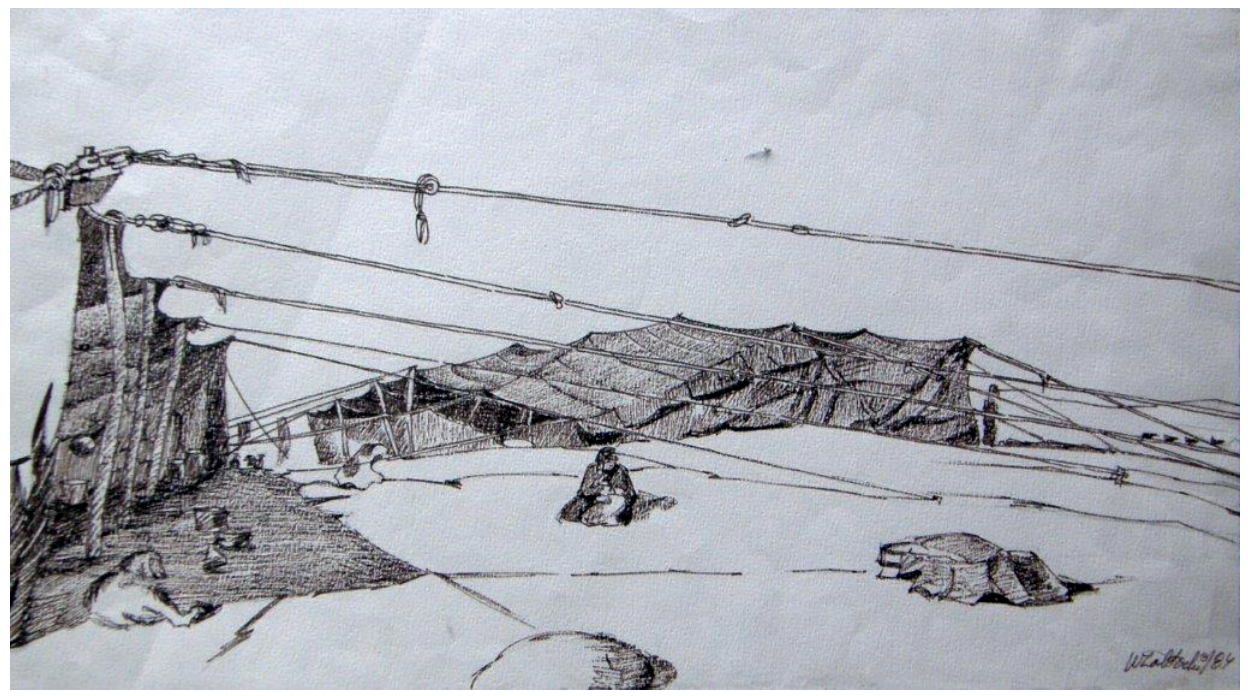

Fig. 4. Concave forms of Bedouin tents were my inspiration to the designs of sport buildings. The drawing was made in the desert near Palmyra 

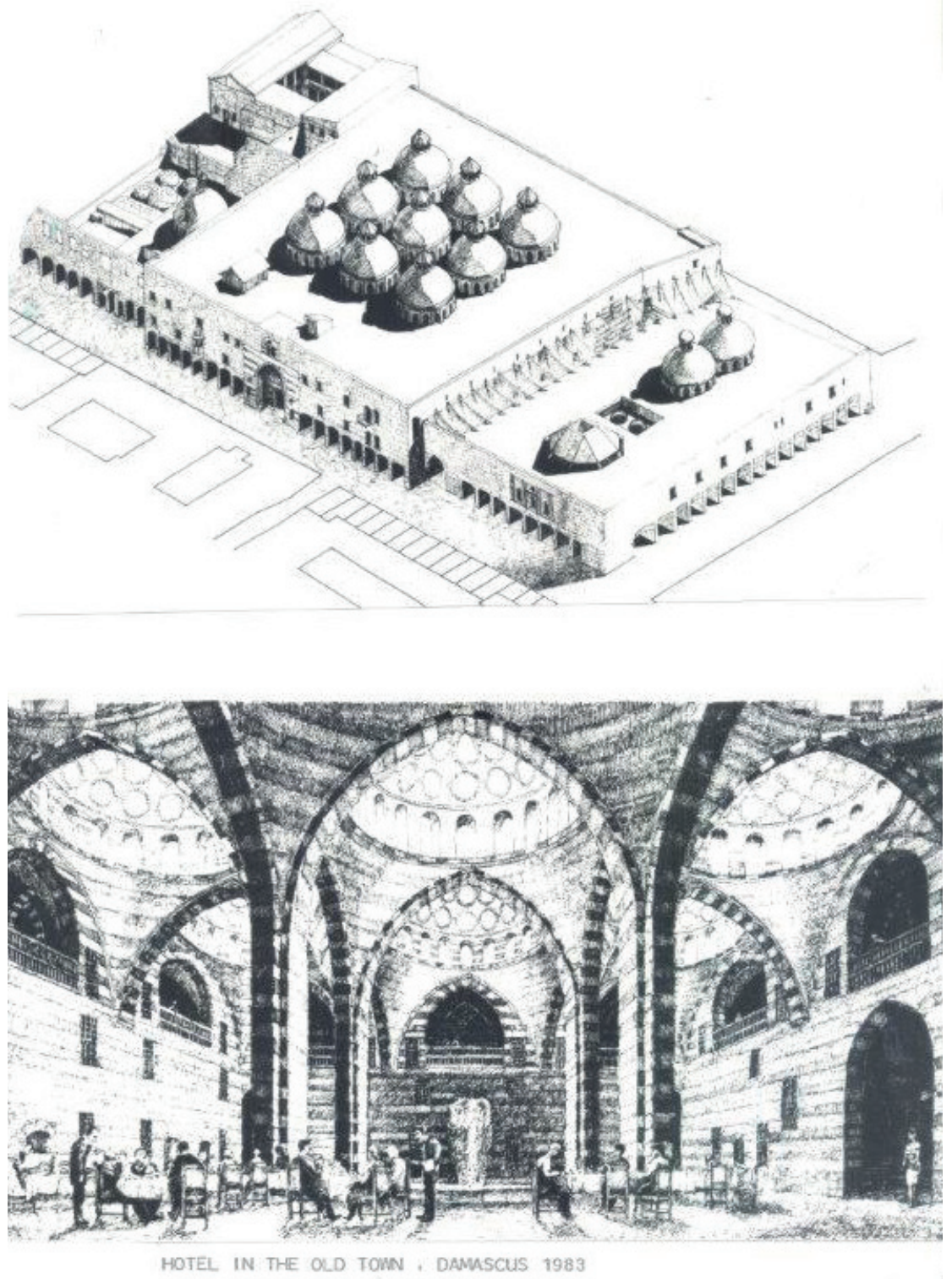

Fig. 5. Refurbishment of the Khan Assad Basha in Damascus. According to its historical use the khan was turned into a modern hotel. In the nearby Khan ar-Riz a VIP hotel was planned, and the market street between the two should serve the hotel shops. Existing hammām ( left, up) was to be used as the hotel swimming pool and spa 


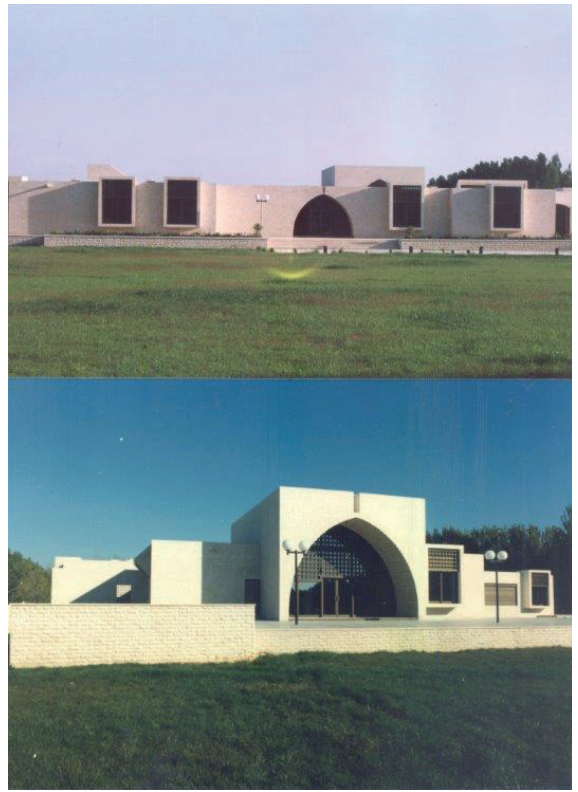

Fig. 6. Family villa near Damscus, outside view. The protruding windows were surely inspired by cantilevered parts of old houses, with a mashrabiyya for women

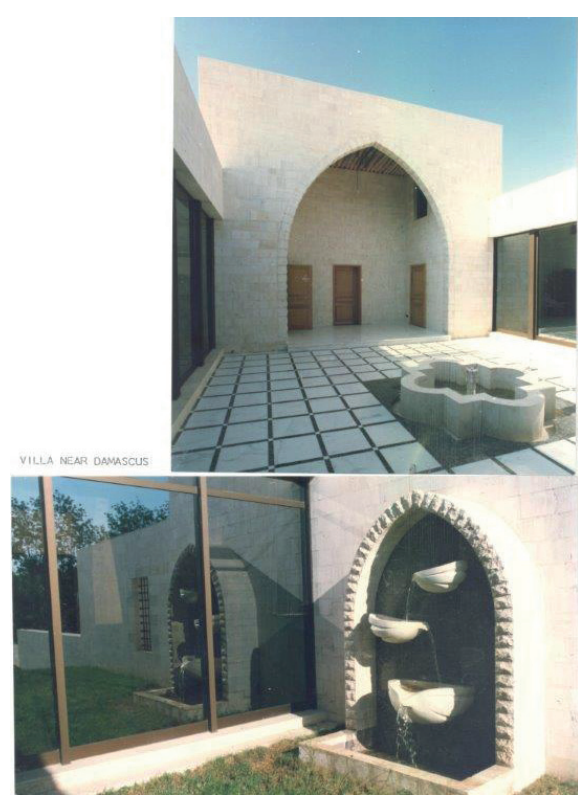

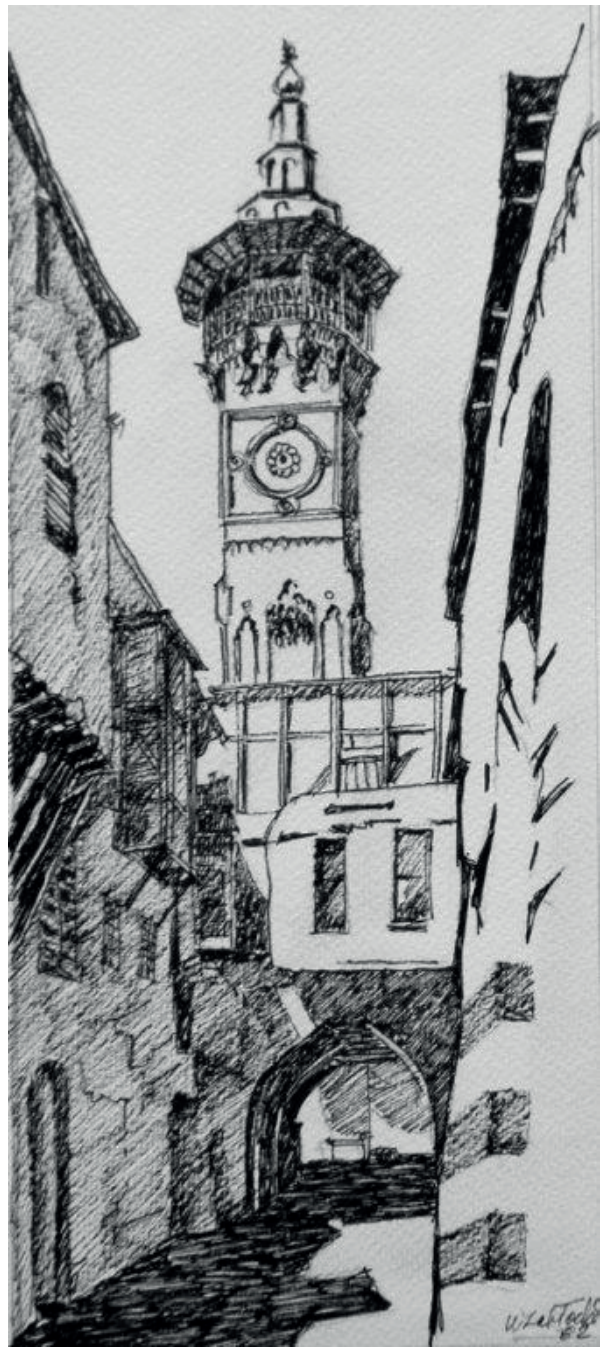

Fig. 7. Old house in Damascus with cantilevers and a mashrabiyya

Fig. 8. Inner court (patio) inside the family villa. I designed the traditional form of īwān with two fountains 


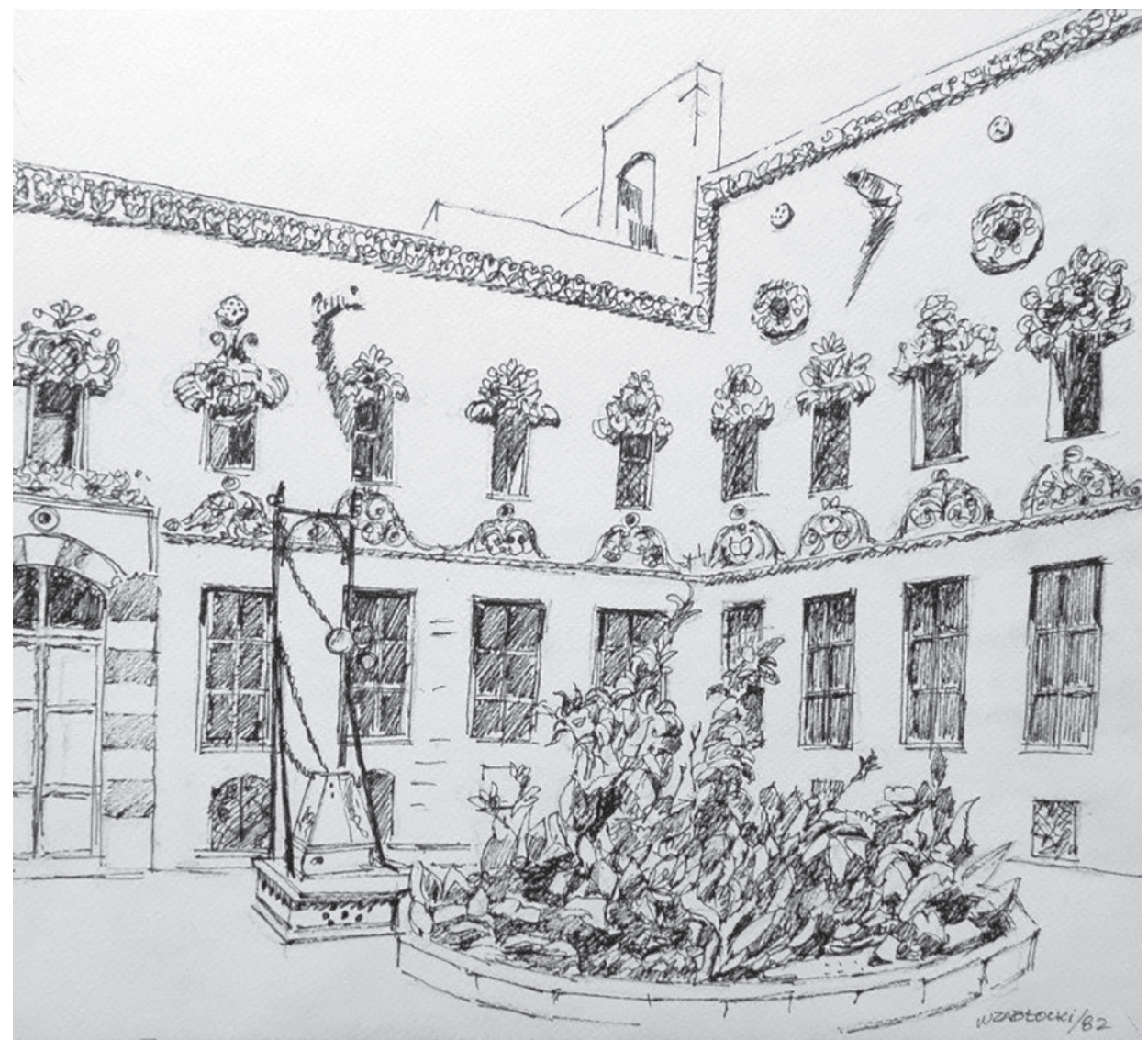

Fig. 9. The inner court of the Ghazala family house in Aleppo, as seen from the îwān 


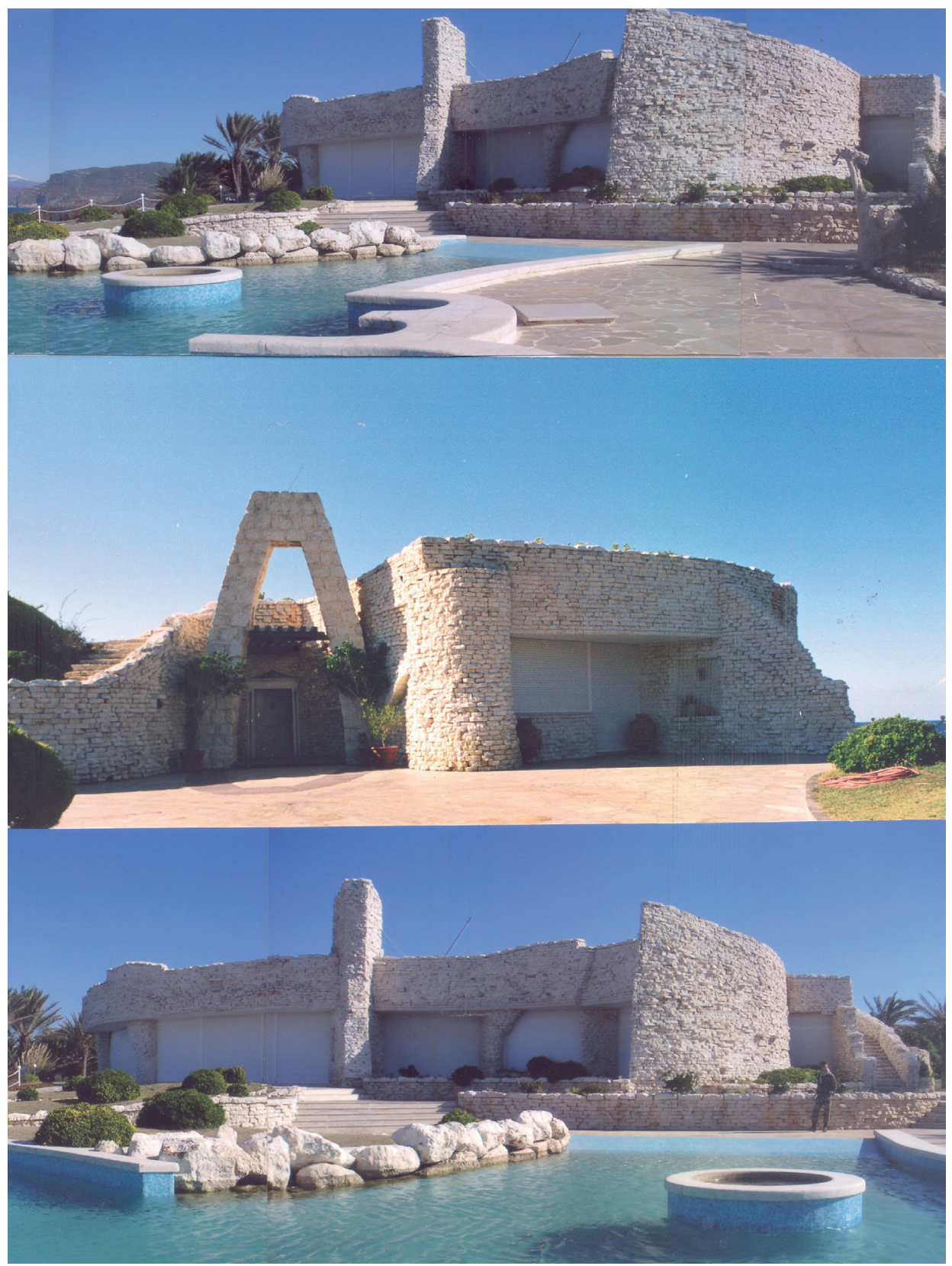

Fig. 10. The holiday villa near Latakia, on the seaside. From entrance the villa is covered by a garden, thus almost invisible. The elevation facing the sea was designed from local stone to give the impression of a cave. The entrance was done in the form derived from the gate to the ancient town of Ugarit, not far from the site 

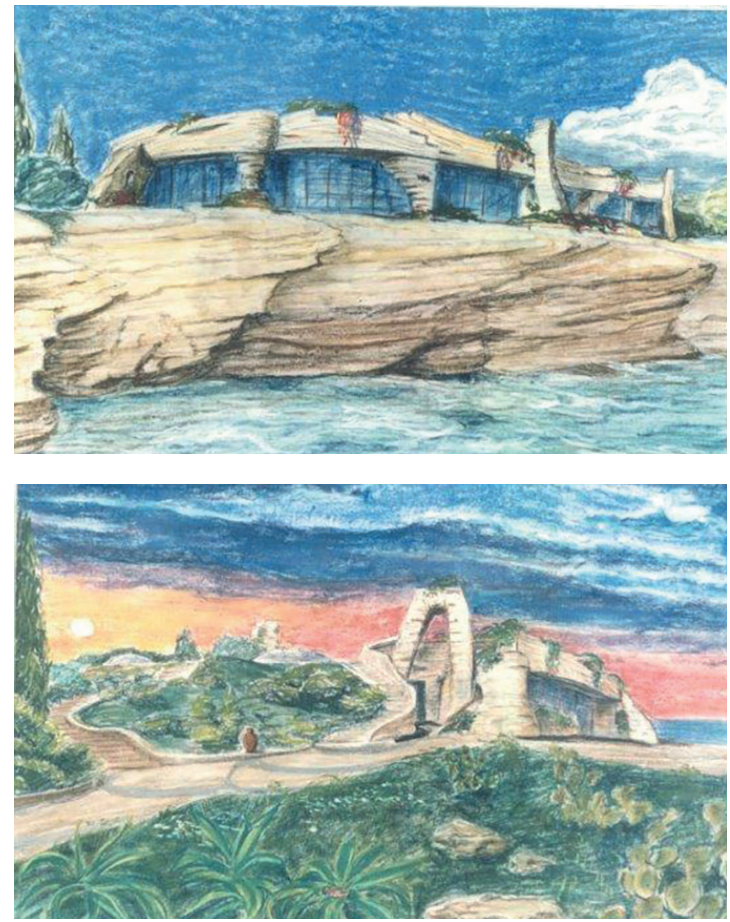

Fig. 11. Another view of the same villa in watercolors.

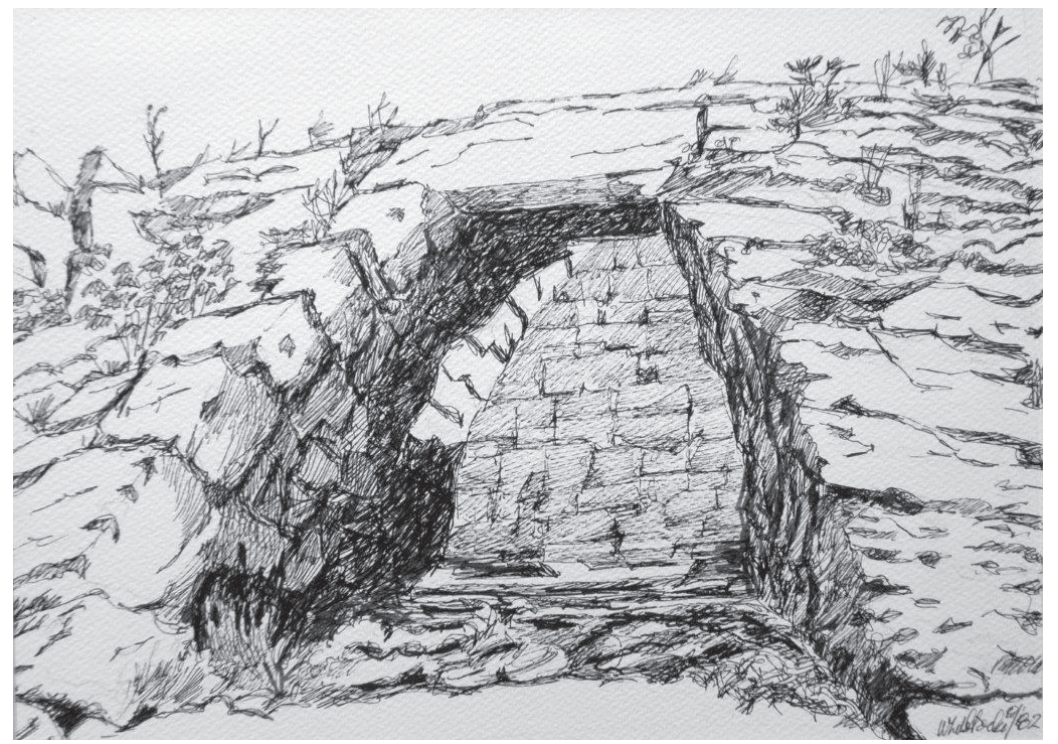

Fig. 12. The arc of Ugarit as seen from down. Although pre-Arabic, this form can be traced in the local architecture 


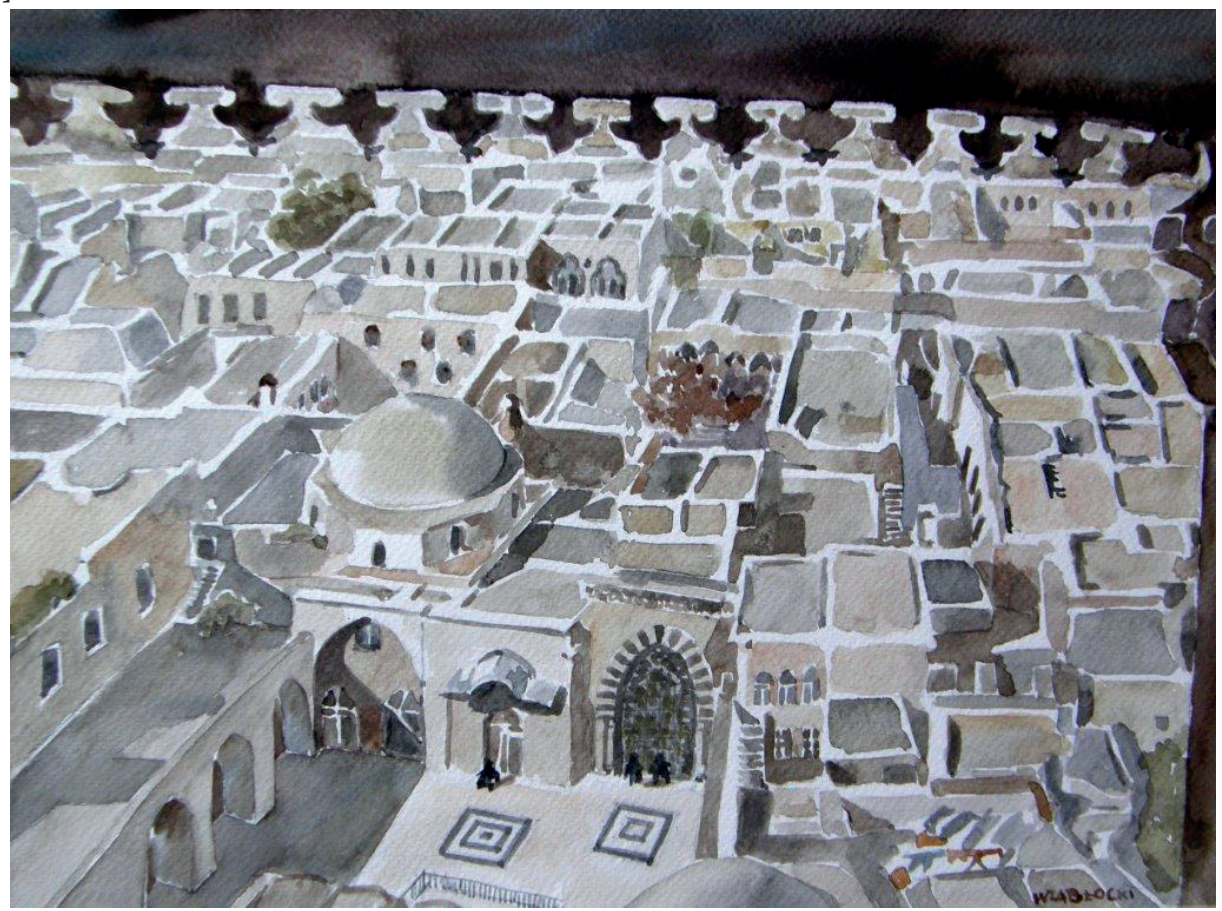

Fig. 13. A typical urban fabric of an Arab town which, I must say, largely inspired my architectural designs

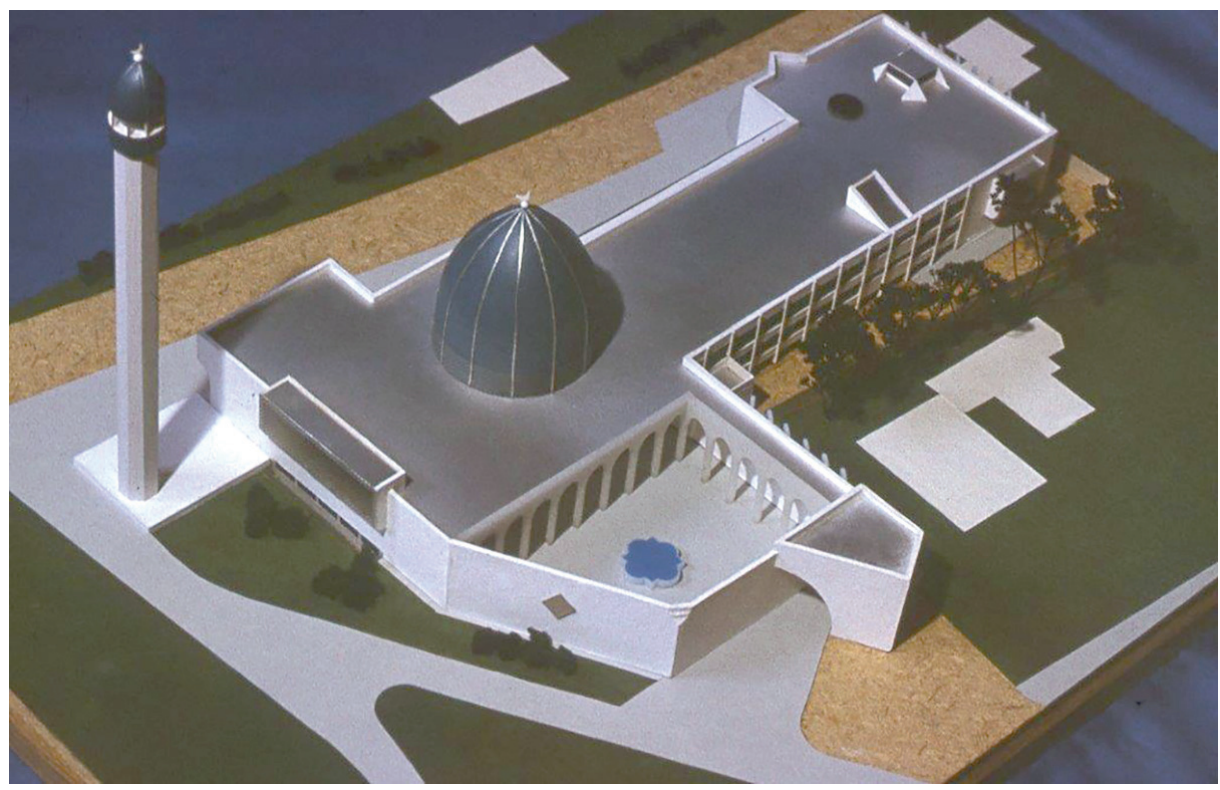

Fig. 14. A maquette of the Warsaw mosque in Bajońska Street (unrealized) 


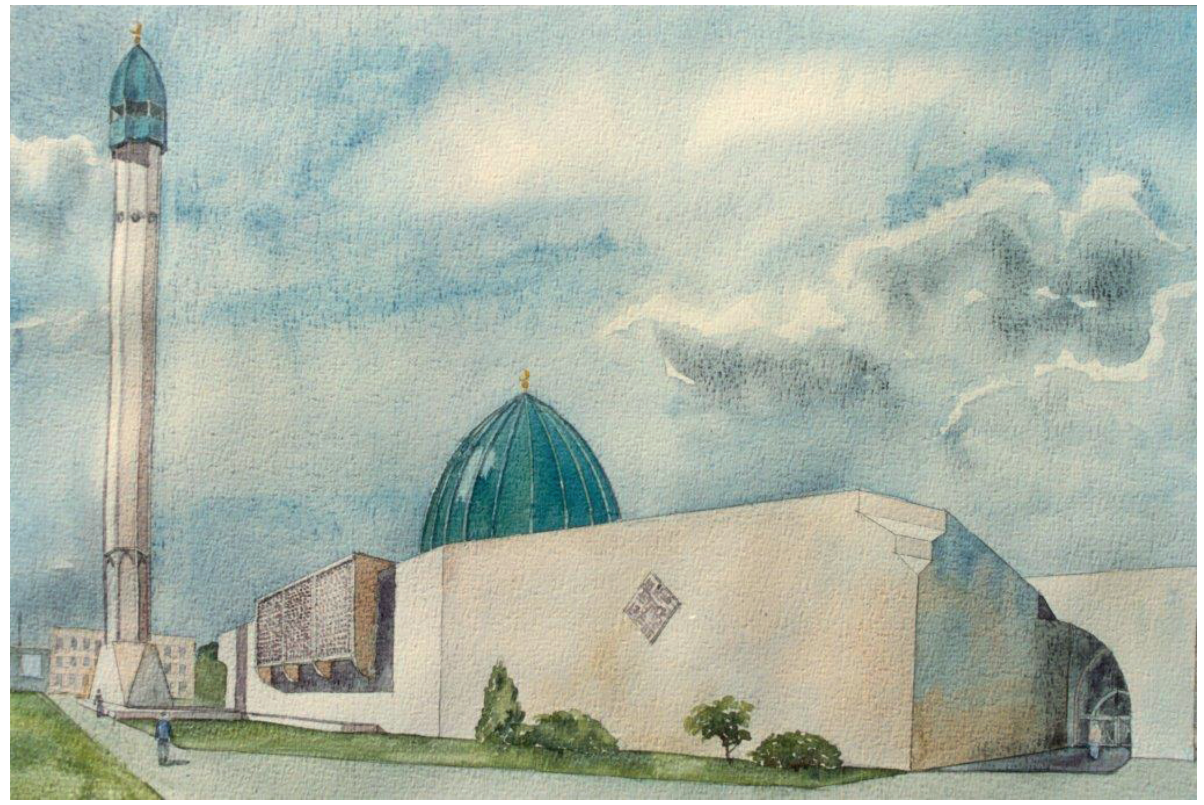

Fig. 15. Outer outlook of the unrealized mosque in Warsaw

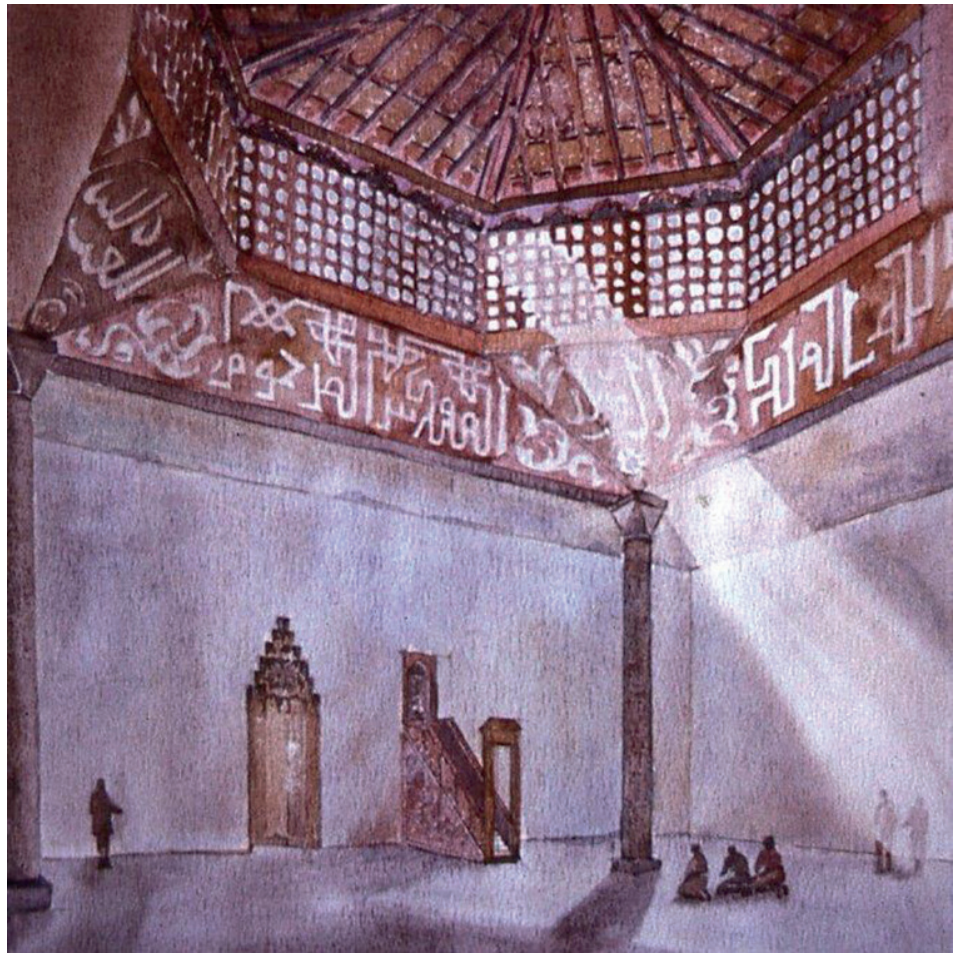

Fig. 16. Inside the men's prayer hall of the Warsaw mosque 